\title{
EFFECTS OF ERYTHROPOIETIN PRETREATMENT ON LIVER, KIDNEY, HEART TISSUE IN PENTYLENTETRAZOL-INDUCED SEIZURES; EVALUATION IN TERMS OF OXIDATIVE MARKERS, PROLIDASE AND SIALIC ACID
}

\author{
PENTILENTETRAZOL-INDÜKLÜ NÖBETLERDE ERITROPOIETIN ÖN TEDAVISININ \\ KARACIĞER, BÖBREK, KALP DOKUSU ÜZERINE ETKILERI; OKSIDATIF MARKIRLAR, \\ PROLIDAZ VE SIALIK ASIT AÇISINDAN DEĞERLENDIRME
}

\author{
Ayşegül KAPUCU ${ }^{1}$ (D) Zülal KAPTAN² (D), Kadriye AKGÜN DAR ${ }^{1}$ (D), İslim KALELER ${ }^{3}$ (D), Gülay ÜZÜM ${ }^{4}$ (D) \\ IIstanbul University, Faculty of Science, Department of Biology, Istanbul, Turkey \\ ${ }^{2}$ Beykent University, Faculty of Medicine, Department of Physiology, Istanbul, Turkey \\ ${ }^{3}$ Istanbul University- Cerrahpasa, Cerrahpaşa Faculty of Medicine, Department of Medical Biochemistry, Istanbul, Turkey \\ ${ }^{4}$ Istanbul University, Istanbul Faculty of Medicine, Department of Physiology, Istanbul, Turkey
}

ORCID IDs of the authors: A.K. 0000-0002-0946-1407; Z.K. 0000-0002-2641-9534; K.A.D. 0000-0003-2060-1199; I.K. 0000-0002-2712-7955; G.Ü. 0000-0003-2329-3689

Cite this article as: Kapucu A, Kaptan Z, Akgun Dar K, Kaleler I, Uzum G. Effects of erythropoietin pretreatment on liver, kidney, heart tissue in pentylentetrazol-induced seizures; evaluation in terms of oxidative markers, prolidase and sialic acid. J Ist Faculty Med 2021;84(4):464-71. doi: 10.26650/IUITFD.2021.883402

\section{ABSTRACT}

Objective: The effects of erythropoietin (EPO) which has been frequently studied as an anti-epileptic agent, on peripheral tissues have not been investigated. This study investigated the effects on malondialdehyde (MDA), advanced protein oxidation products (AOPP), superoxide dismutase (SOD), prolidase and sialic acid (SA) levels in the heart, kidney and liver tissues of EPO pretreatment in pentylenetetrazole (PTZ)-induced seizures.

Material and Method: Thirty three male adult rats were divided into three groups. A saline-injected control group, a $60 \mathrm{mg} / \mathrm{kg}$ PTZ-injected group to induce seizures and a 3000 IU/kg EPO-injected group 24 hours before seizures. After seizure severity and seizure latency were scored, the rats sacrificed, the tissues were immediately removed for biochemical analyses.

Results: The PTZ-induced seizures increased MDA in kidney $(p<0.01)$ and AOPP in liver $(p<0.05)$ but didn't alter these markers in heart tissue. In all three tissues, SOD didn't change due to seizures. The SA levels increased in the heart $(p<0.001)$, decreased in the kidney $(p<0.001)$, and were unchanged in liver. Prolidase increased $(p<0.05)$ only in kidney, and was unchanged in other tissues. EPO-pretreatment decreased seizure severity and increased seizure latency. It prevented the increase in MDA in the kidney $(p<0.01)$ but increased AOPP $(p<0.05)$ and

\section{ÖZET}

Amaç: Antiepileptik ajan olarak sıklıkla çalışılan eritropoietinin (EPO)'nun periferik dokular üzerindeki etkileri araştırılmamıştır. Bu çalışmada pentilentetrazol (PTZ) ile indüklenen nöbetlerde EPO ön tedavisinin kalp, böbrek ve karaciğer dokularında malondialdehit (MDA), ileri protein oksidasyon ürünleri (AOPP), superoksid dismutaz (SOD), prolidaz ve sialik asit (SA) seviyelerine etkisi araştıııldı.

Gereç ve Yöntem: Otuz üç erişkin erkek sıçan üç gruba ayrıldı. Salin enjekte edilmiş kontrol grubu, nöbetleri indüklemek için 60 mg/kg PTZ enjekte edilmiş grup, nöbetlerden 24 saat önce $3000 \mathrm{IU} / \mathrm{kg}$ EPO enjekte edilmiş grup. Nöbet şiddeti ve nöbet gecikmesi puanlandıktan sonra, sıçanlar sakrifiye edildi, dokular biyokimyasal analizler için hemen çıkarıldı.

Bulgular: Pentilentetrazol ile indüklenen nöbetler, böbrekte MDA $(p<0,01)$ ve karaciğerde AOPP'yi arttırdı $(p<0,05)$, ancak kalp dokusunda bu markırları değiştirmedi. Her üç dokuda da SOD nöbetler nedeniyle değişmedi. Kalpte SA arttı $(p<0,001)$, böbrekte azaldı $(p<0,001)$, karaciğerde değişmedi. Prolidaz sadece böbrekte arttı $(p<0,05)$, diğer dokularda değişmedi. EPO ön tedavisi nöbet şiddetini azalttı ve nöbet latansını artırdı. EPO böbrekte MDA artışını engelledi $(p<0,01)$, ancak AOPP'yi artırdı $(p<0,05)$ ve SOD'u azalttı $(p<0,01)$ ve prolidazı nöbetlerin arttırdı-

Corresponding author/iletişim kurulacak yazar: gulayuzum@gmail.com

Submitted/Başvuru: 19.02.2021 • Revision Requested/Revizyon Talebi: 30.03.2021 •

Last Revision Received/Son Revizyon: 19.04.2021 • Accepted/Kabul: 19.04.2021 • Published Online/Online Yayın: 14.09.2021 
decreased SOD $(p<0.01)$ and further increased prolidase more than the seizures increased $(p<0.01)$. EPO-pretreatment prevented the increase in AOPP in the liver $(p<0.05)$ but was ineffective in PTZ-induced SA changes in the heart and kidney.

Conclusion: We think that the increase in the heart SA level in seizures is an original finding and deserves investigation in the context of seizure-related cardiac arrhytmias. Also, despite the EPO's anti-seizure effect, increased protein oxidaiton and prolidase, especially in the kidney, is an other important finding that needs further research.

Keywords: Erythropoietin, PTZ-induced seizures, oxidative stress markers, sialic acid, prolidase, peripheral tissues ğından daha fazla artırdı $(p<0,01)$. EPO ön tedavisi, karaciğerde AOPP artışını önledi $(p<0,05)$, ancak kalp ve böbrekte PTZ'nin neden olduğu SA değişikliklerinde etkisizdi.

Sonuç: Nöbetlerde kalp dokusundaki SA artışının nöbet-ilişkili kardiak aritmiler bağlamında araştırmayı hak eden orijinal bulgu olduğunu düşünüyoruz. Ayrıca EPO ön tedavisinin nöbet engelleyici etkisine rağmen özellikle böbrek dokusunda artmış protein oksidasyonu ve prolidaz da ileri araştırmayı gerektiren diğer önemli bulgudur.

Anahtar Kelimeler: Eritropoietin, PTZ-indüklü nöbetler, oksidatif stres belirteçleri, sialik asit, prolidaz, periferik dokular

\section{INTRODUCTION}

It is demonstrated that epileptic seizures cause oxidative stress (OS) not only in the central nervous system but also in peripheral tissues (1). OS is an issue caused by an imbalance between the production of reactive oxygen species (ROS) in tissues and the capacity of endogenous antioxidant defense systems to remove these reactive products. Superoxide dismutase (SOD), one of the important antioxidant enzymes in the body, plays a key role in detoxifying superoxide anions and may prevent OS-induced cellular damage (2). It is shown that experimental induced epileptic seizures increase lipid peroxidation and decrease SOD enzyme activity in liver and kidney (2). On the other hand, it is reported that various anti-epileptic drugs (AEDs) are insufficient in preventing seizures and may trigger $O S$ in brain and peripheral tissues, impair the endogenous antioxidative ability. Thus, epilepsy patients are suffering from hepatic and renal dysfunctions due to their current anti-epileptic drug treatment (1). For instance, it is shown that commonly used drugs such as sodium valproate is associated with serious hepatotoxicity (3). Thus, novel AED investigations that suppress seizures more efficiently with no or minimum adverse effects draw attention. Erythropoietin (EPO) is a hypoxia inducible hematopoietic factor, which is predominantly expressed in the kidneys. However, EPO and its receptors are widely expressed in many tissues including brain, liver, skeletal, heart, muscle and lungs (4). There are many studies showing the anti-epileptic effect of EPO (5-7). In our previous studies, we have shown its antioxidant and anti-inflammatory effects on brain tissue in addition to antiseizure effect of EPO treatment in a generalized acute tonic-clonic epilepsy model induced by pentylenetetrazole (PTZ) in rats $(6,7)$. However, although EPO's anti-epileptic property is shown, it is an important deficiency that its effects on peripheral tissues have not been investigated yet. EPO has been shown to have an antioxidant effect and a protective effect on heart tissue and kidney ischemia/reperfusion injury models $(4,8,9)$. These reports led us to ask what effect EPO treatment might have on the OS that may occur in peripheral tissues in epileptic seizures.
Because of detoxification and excretion functions, the liver and kidney are two important organs that have been investigated in the context of side effects such as OS in experimental seizure models $(2,10)$. On the other hand, it is reported that drug refractory epilepsy patients have cardiovascular abnormalities and epilepsy is associated with the risk of cardiac ischemia (11). Also, it is known that sudden cardiac arrest and heart rhythm disorders are considered the most common cause of epilepsy-related deaths (12). However, the effects of seizures and anti-epileptic drugs on heart tissue have not been investigated. Voltage-gated sodium channels which include negatively charged sialic acid (SA) is vital for neuronal signal conduction and regular heart rhythms (13). Sialic acid can directly activate the voltage dependent sodium channel at lower depolarization via contributing to negative potential (14). In this context, if SA may affect heart muscle excitability, how epileptic seizures and anti-epileptic drugs affect SA levels in heart muscle is an issue that needs to be investigated, but as far as we know, no such study has been conducted before. Besides the effects of epileptic seizures and anti-epileptic drugs on heart tissue have not been investigated in terms of other biomarkers.

Prolidase is a metalloenzyme that is found in many tissues including the kidney, brain, heart, lungs, and pancreas (15). It plays a role in the recycling of proline from imidodipeptides for the resynthesis of collagen, the main component of the connective tissue and therefore it provides collagen turnover, and matrix remodeling (16). It is also reported that prolidase enzyme activity may be induced with $O S$ and inflammation, also disturbances in prolidase enzyme activity can contribute to the damaging effects of free radicals through collagen breakdown and may play a role in the progress of various diseases (17). Besides, it is shown that serum prolidase enzyme activity and OS values increased in epileptic patients taking anti-epileptic drug and it is reported that this may be a risk factor for vascular damage because of the increase in the collagen cycle (18). To the best of our knowledge, there is no data on how the epileptic seizures affect prolidase 
activity in kidney, liver, and heart tissues and how the EPO treatment changes it.

In light of this information, in this study, we essentially focused the effects of PTZ-induced acute generalized tonic clonic seizures as well as EPO pretreatment 24 hours before PTZ administration on liver, kidney and heart tissues. We evaluated these effects in terms of SA levels, prolidase activity, advanced oxidation protein products (AOPP; protein oxidation indicator), malondialdehyde (MDA; lipid peroxidaiton indicator) and SOD levels.

\section{MATERIAL AND METHOD}

\section{Animals and experimental design}

Male Wistar albino rats (200-250g) were housed in cages and $12 \mathrm{~h}$ light-dark cycle and an ad libitum feeding were maintained. Experiments were conducted in the morning to avoid circadian variations. All procedures were done in accordance with the guidelines of Bezmialem Vakif University Animal Experiments Local Ethics Committee (Date: 22.04.2016, No:128).

Thirty three rats were randomly divided into three groups ( $n=11 /$ each group); 1: Control group (administered with $0.9 \%$ saline), 2: PTZ group (administered with $60 \mathrm{mg} /$ $\mathrm{kg}$ PTZ to induce generalized tonic-clonic seizures), 3: EPO+PTZ group (administered with $3000 \mathrm{lU} / \mathrm{kg}$ EPO 24 h before PTZ injection). PTZ (Sigma, St. Louis, MO, USA), and Recombinant human EPO (r-HuEPO, Eprex; Epoetin alfa, Santa Farma, Turkey) were dissolved in $0.5 \mathrm{ml} 0.9 \%$ saline and administered intraperitoneally. PTZ dose was selected as it achieves the most successful convulsive response with the least mortality (19). The EPO dose is the dose that does not have any side effects that do not affect the hematocrit values and has anticonvulsive activity (7).

\section{PTZ-induced seizures}

Pentilentetrazol is commonly used to create a model of generalized seizure in rats and to study the effectiveness of anti-epileptic drugs (7). A single dose $60 \mathrm{mg} / \mathrm{kg}$ PTZ intraperitoneally was injected to induce tonic-clonic generalized seizures. After the PTZ injection, the rats were placed in a plexiglass acrylic cage and seizure behavior was observed until convulsions stopped and was recorded with a camera. The severity of seizures were assessed, using scores based on modified Racine's scale (20), as follows: 1 , ear and facial twitching; 2 , head bobbing and repeated myoclonic jerks; 3, partial clonic forelimb convulsions in a sitting position; 4, major seizures (generalized tonic-clonic seizures whilst lying on the belly); 5, generalized tonic-clonic seizures; running, followed by the loss of righting ability, and then a tonic phase progressive to the clonus of all four limbs. Seizure latency was measured as the time between the injection of PTZ and the appearance of the first myoclonic jerks.

\section{Biochemical analysis of AOPP, MDA, SOD, SA and pro- lidase enzyme activity in liver, heart, and kidneys} After the evaluation of seizure severity, rats were decapitated under anesthesia (50 mg/kg ketamine and 10 $\mathrm{mg} / \mathrm{kg}$ xylazine) and the liver, heart and kidneys were removed immediately. The kidney, heart and liver tissues were washed in ice cold 0.01 M PBS (Phosphate Buffered Saline) to avoid blood contamination. All tissue samples were homogenized in 0.01 M PBS (pH 7.4) using Teflon/ glass homogenizer and the homogenates were centrifuged at $5,000 \mathrm{~g}$ for $15 \mathrm{~min}$ at $4^{\circ} \mathrm{C}$. The supernatants were aliquoted and stored at $-80^{\circ} \mathrm{C}$ immediately until AOPP, MDA, SA levels and SOD, prolidase activity assay were performed. The total amount of protein was determined by the Lowry method (21).

AOPP assays were performed spectrophotometrically at $340 \mathrm{~nm}$ wavelength by Hanasand's modified method (22). AOPP concentrations were calculated from the standard curve graph and expressed as $\mu \mathrm{mol} / \mathrm{L}$ chloramine-T equivalents.

Changes in tissue lipid peroxidation levels were evaluated by measuring MDA levels. Spectrophotometric analysis of MDA levels was performed by Beuge and Aust's method (23), determined by the quantity of thiobarbituric acid reactive products. The MDA concentration was calculated by its molar extinction coefficient $\left(\varepsilon=155 \mathrm{mM}^{-}\right.$ $1 \mathrm{~cm}^{-} 1$ ) and expressed as nmol/mg protein.

SA levels were determined by the Tram method (24). B-formylpyruvic acid formed because of periodic acid oxidation was reacted with two molthiobarbituric acid. A colored compound was formed that gave maximum absorbance at $549 \mathrm{~nm}$. Since this product is not stable, absorbances were recorded at $549 \mathrm{~nm}$ in the spectrophotometer by pulling into the cyclohex-zanon phase. The SA amount was expressed as $\mu \mathrm{g} / \mathrm{mg}$ protein.

The total SOD enzyme activity was measured spectrophotometrically (25). The percent inhibition rate was calculated with the formula Ablank-Asample/Ablank x 100 . $50 \%$ inhibition corresponds to 1 Unit of enzyme activity. Enzyme activity was given as $\mathrm{U} / \mathrm{mg}$ protein.

Prolidase enzyme activity was determined according to the spectrophotometric method of Ozcan et al. 2007 (26), based on the measurement of proline levels, a prolidase product, produced by prolidase enzyme. Tissue prolidase activities were expressed in terms of $\mathrm{nmol} / \mathrm{min} / \mathrm{mg}$ protein.

\section{Statistical analysis}

The levels of AOPP, MDA, SOD, SA and prolidase enzyme activity in the liver, heart and kidneys were analyzed separately. The comparisons between groups were made by unpaired t tests in GraphPad Prism 8 software. A value of $p<0.05$ was considered statistically significant. 


\section{RESULTS}

\section{Evaluation of PTZ-induced seizures}

A single dose of $60 \mathrm{mg} / \mathrm{kg}$ PTZ caused generalized tonic clonic epileptic seizures of 4-5 severity according to the Racine's scale. EPO pretreatment significantly reduced the severity of seizures and increased seizures latency (Table 1). As seizures were not observed in the control group, it was not included in the table.

Table 1: Seizure severity and Seizure latency in PTZ and EPO+PTZ groups

\section{PTZ EPO+PTZ p value}

Seizure latency (Sec) $74.86 \pm 6.02 \quad 101.1 \pm 8.54 \quad p<0.05$

$\begin{array}{llll}\text { Seizure severity } \quad 4.8 \pm 0.4 & 3.4 \pm 0.5 & p<0.01\end{array}$

PTZ: single dose of $60 \mathrm{mg} / \mathrm{kg}$ pentylenetetrazol was administered; EPO+PTZ: $3000 \mathrm{IU} / \mathrm{kg}$ erythropoietin was administered 24 hours before a PTZ injection. Seizures were not seen in control group, therefore they are not given in the table.

\section{Evaluation of OS markers, prolidase and SA levels in peripheral tissues}

When the changes in the OS markers, prolidase and SA levels in peripheral tissues were examined, different results were observed for all three organs. The variation of each parameter according to the groups was as follows.

AOPP; PTZ induced seizures caused an increase in AOPP in liver tissue compared to the control group $(p<0.05)$ but did not change in heart and kidney AOPP levels compared to the control group (Figure 1). EPO treatment before seizures decreased AOPP level in the liver compared to the PTZ group $(p<0.05)$. Conversely, it further increased AOPP level in kidney compared to the PTZ group $(p<0.01)$ (Figure 1). EPO pretreatment did not significantly cause change in terms of AOPP in heart tissue.

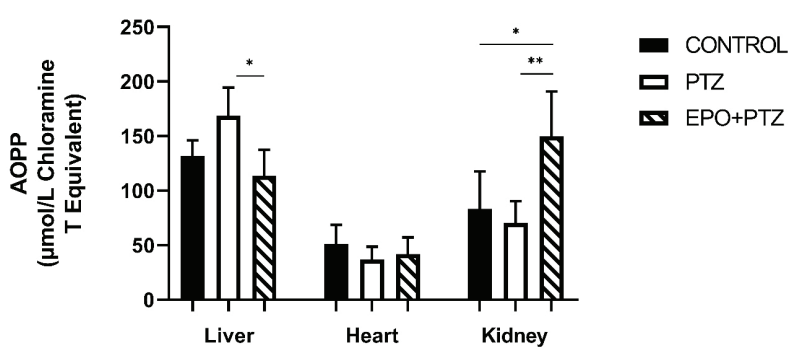

Figure 1: AOPP levels in liver, heart and kidney tissues in all groups

AOPP: Advanced oxidation protein products; Control: $0.9 \%$ saline was administered; PTZ: single dose of $60 \mathrm{mg} / \mathrm{kg}$ pentylenetetrazol was administered; EPO+PTZ: $3000 \mathrm{lU} / \mathrm{kg}$ erythropoietin was administered 24 hours before a pentylenetetrazol injection. Each column represents the mean $\pm \mathrm{SD} .{ }^{*} \mathrm{p}<0.05 ;{ }^{*} \mathrm{p}<0.01$
MDA; PTZ-induced seizures increased kidney MDA level compared to control group $(p<0.01)$. Conversely, it did not cause to any change in MDA levels in liver and heart tissues compared to the control group (Figure 2). EPO treatment before seizures significantly decreased MDA levels in heart $(p<0.05)$ and kidney $(p<0.01)$ compared to PTZ group (Figure 2). But EPO pretreatment did not cause any change in liver MDA level compared to other groups (Figure 2).

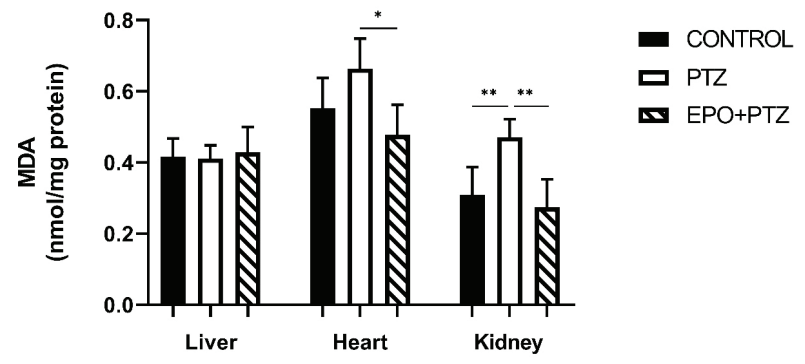

Figure 2: MDA levels in liver, heart and kidney tissues in all groups

MDA: Malondialdehyde. Control: $0.9 \%$ saline was administered; PTZ: single dose of $60 \mathrm{mg} / \mathrm{kg}$ pentylenetetrazol was administered; EPO+PTZ: $3000 \mathrm{IU} / \mathrm{kg}$ erythropoietin was administered 24 hours before a pentylenetetrazol injection. Each column represents the mean $\pm S D .{ }^{*} p<0.05 ;{ }^{*} p<0.01$

SOD; PTZ-induced seizures did not change SOD levels of liver, heart and kidney tissues according to the control group (Figure 3). EPO treatment before seizures did not cause significant difference in liver and heart tissues' SOD levels, but EPO pretreatment significantly caused a decreased SOD level in kidney compared to the PTZ and control groups ( $p<0.001$ and $p<0.01$, respectively) (Figure 3).

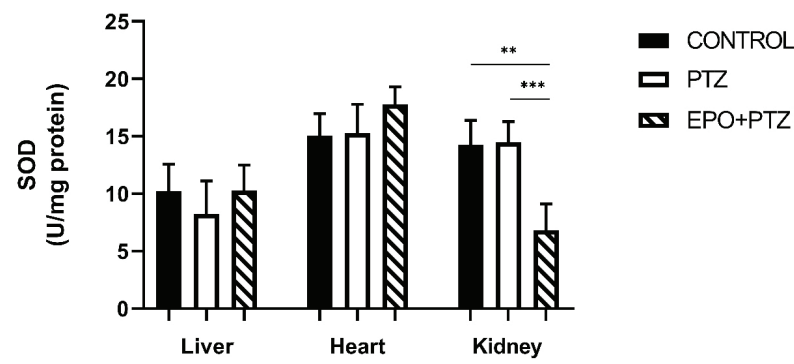

Figure 3: SOD levels in liver, heart and kidney tissues in all groups

SOD: Superoxide dismutase. Control: $0.9 \%$ saline was administered; PTZ: single dose of $60 \mathrm{mg} / \mathrm{kg}$ pentylenetetrazol was administered; EPO+PTZ: $3000 \mathrm{IU} / \mathrm{kg}$ erythropoietin was administered 24 hours before a pentylenetetrazol injection. Each column represents the mean \pm SD. ${ }^{* \star} p<0.01 ;{ }^{* \star \star} p<0.001$ 
SA; PTZ induced seizures significantly caused an increase in the heart SA level compared to the control group $(p<0.001)$. Conversely, it caused a significant decrease in the kidney tissue SA level compared to the control group $(p<0.001)$. But it did not cause a difference in liver SA level compared to the control group (Figure 4). In the EPO pretreated group all tissue SA levels were the same as in the PTZ group. In other words, in the EPO treatment group, as in the PTZ group, the SA level in the heart tissue was higher than the control group $(p<0.05)$, it was lower in the kidney tissue compared $(p<0.001)$. EPO pretreatment also did not cause a significant change in the liver SA level as in the PTZ group (Figure 4).

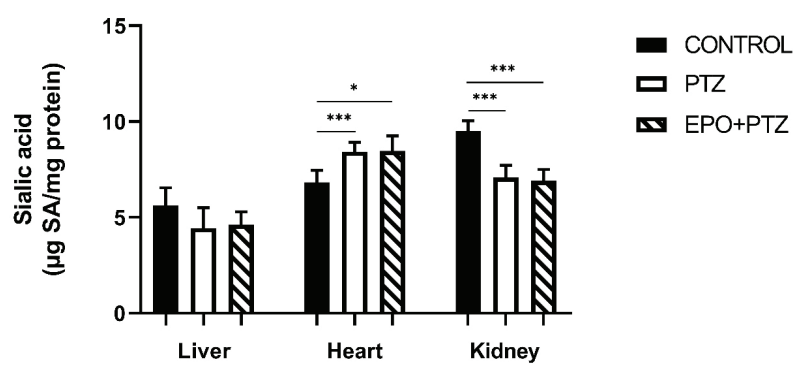

Figure 4: Sialic acid levels in liver, heart and kidney tissues in all groups

Control: $0.9 \%$ saline was administered; PTZ: single dose of 60 $\mathrm{mg} / \mathrm{kg}$ pentylenetetrazol was administered; EPO+PTZ: 3000 IU/ $\mathrm{kg}$ erythropoietin was administered 24 hours before a pentylenetetrazol injection. Each column represents the mean \pm SD. ${ }^{*} \mathrm{p}<0.05 ;{ }^{* \star *} \mathrm{p}<0.001$

Prolidase; PTZ-induced seizures did not cause a change in liver and heart tissues prolidase level compared to the control group but increased in the kidney prolidase level in comparison $(p<0.05)$ (Figure 5). EPO treatment before seizures increased the kidney prolidase level $(p<0.05)$, but EPO pretreatment did not cause a change in liver and heart tissues prolidase levels compared to other groups (Figure 5).

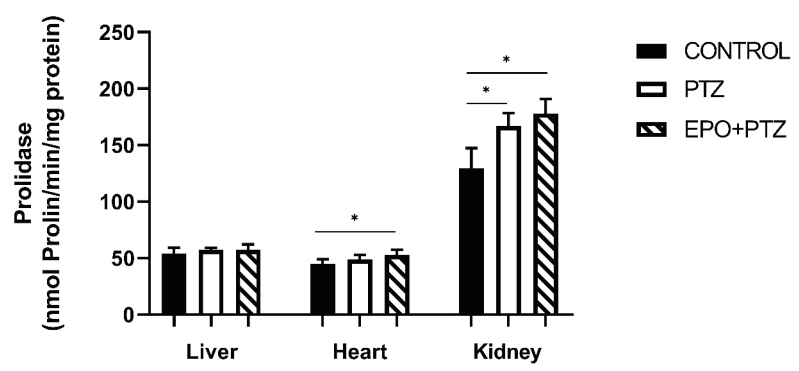

Figure 5: Prolidase levels in liver, heart and kidney tissues in all groups

Control: $0.9 \%$ saline was administered; PTZ: single dose of $60 \mathrm{mg} /$ $\mathrm{kg}$ pentylenetetrazol was administered; EPO+PTZ: $3000 \mathrm{IU} / \mathrm{kg}$ erythropoietin was administered 24 hours before a pentylenetetrazol injection. Each column represents the mean \pm SD. ${ }^{\star} p<0.05$

\section{DISCUSSION}

It is demonstrated that PTZ-induced seizures in rats increased the MDA level, which is a lipid peroxidation indicator in the liver and kidney and also the brain (10, 27). Although our findings are consistent with other studies in terms of the OS increase in the liver and kidney, it is original because it shows a difference because the oxidative biomarkers differ according to tissues. PTZ induced seizures did not cause significant changes in oxidative markers in heart tissue, but it increased MDA in the kidney and AOPP in the liver, it did not decrease SOD, which is an antioxidant enzyme in both tissues. Antioxidant markers are expected to decrease while oxidative markers increase (28). The fact that the SOD level was not decreased in our study suggested an increase in the activity of the endogenous defense system against the OS caused by seizures in tissues. Indeed, supporting our suggestion, studies done in patients with epilepsy have shown that there is an increase in oxidative markers in plasma that show protein, lipid and DNA oxidation, and an increase in antioxidant enzymes (29).

Another OS related parameter we investigated in our study was prolidase, which is one of the matrix metalloproteinases. It was shown that increased prolidase enzyme activity and total oxidant markers in the serum of epileptic patients taking the anti-epileptic treatment may have an increased risk for vascular damage associated with degenerated collagen turnover (18). In our study PTZ-induced seizures increased the level of prolidase only in kidney tissue, it did not change in other tissues. When we consider that PTZ-induced seizures cause an increase in MDA, which is lipid peroxidation indicator, in the kidney we suggested that an increase in prolidase may be associated with lipid peroxidation in particular.

Pentilentetrazol induce seizures by activating glutamate receptors and inhibiting GABA receptors (20). Glutamate receptors have been also identified in tissues such as those of the liver, kidney, lung, and heart and also the brain (30). Thus, seizures might affect peripheral tissues through glutamate receptors. Also, it is reported that $\mathrm{N}$-methyl-D-aspartate (NMDA) receptors, which are a subtype of glutamate receptors could be one of the crucial mediators in the regulation of oxidative balance in many tissues. Although the functional significance of glutamate receptors for kidney, liver and other tissues is not exactly understood, it is suggested that sustained activation of these receptors induces changes in cellular calcium dynamics and in turn can activate free radical generation, that is lipid peroxidation (30). A study targeting glutamate receptors has reported that type-5 metabotropic glutamate receptor (mGlu5) antagonist (MPEP) administration might protect erythrocytes and liver tissue against anoxic damage and prevent increase in OS re- 
vealed by PTZ-induced seizures in rats (10). In our study, the fact that epileptic seizures increased prolidase and MDA, especially in the kidney, may be due to containing more glutamate receptors of the kidney. Indeed, it is reported that the kidney contains more and all types of glutamate receptors (30). In another study it is reported that OS related tissue damage in renal cells may be caused by excessive activation of NMDA glutamate receptors (31).

In this study we also investigated the change of SA in peripheral tissues following seizures. We found that PTZ-induced seizures caused a significant increase in the level of SA only in the heart tissue. We think this is important because seizures related to cardiac rhythm disorders are an important problem and we suggest this may be related to SA. Indeed, it is proposed that the serum SA content is associated with cardiovascular diseases. It is shown that the SA level was elevated in serum after myocardial infarction (32). Moreover, a relationship between an increase in SA biosynthesis and cardiac hypertrophy was demonstrated (33). We think that studies investigating the significance of SA in heart rhythm disturbances or sudden deaths observed in epileptic seizures are needed.

As far as we know, this study is the first study investigating changes in SA levels in the heart and other tissues in epileptic seizures. Interestingly in our study PTZ-induced seizures lowered SA levels in the kidney. It is suggested that SA acts as a competitive antagonist at the glutamate binding site (34). Non-neural glutamate receptors may play a role in normal cellular functions such as cell to cell communication. Also, all the ionotropic glutamate receptors, especially NMDA receptors are nonselective cation channels, allowing the passage in small amounts of $\mathrm{Ca}^{+2}(30,35)$. We think that the decrease in SA in the kidney tissue and thus the increase in $\mathrm{Ca}^{+2}$ entry into the cell may have triggered OS. On the other hand, PTZ-induced seizures increased the SA level in heart tissue. We thought that the increased SA in the heart tissue caused of seizures might have prevented $\mathrm{Ca}^{+2}$ entry into the heart cell, so the increase of OS products in the heart tissue may have been prevented. As a matter of fact, in our study, oxidative markers did not increase in the heart tissue because of the seizures. However, we thought that the excitability of the heart may change because of the increase in SA in the heart tissue that might prevents $\mathrm{Ca}^{+2}$ entry into the cell. From this point of view, the effects, and consequences of seizures on SA levels in the kidney and heart tissues are important subjects that require further investigation.

In our study, we also investigated the effects on peripheral tissues besides the anti-epileptic effect of EPO pretreatment in seizures. As previously shown by our studies $(7,19)$, also in the present study EPO pretreatment decreased the severity of PTZ-induced seizures and increased the seizure latency. EPO pretreatment prevented an MDA increase caused by seizures in the kidney, while increasing the level of AOPP, which was not changed with seizures. It has been reported that AOPP, which are protein oxidation products, are more reliable than lipid peroxidation products as OS indicators due to their stability and longevity (36). Therefore, although EPO pretreatment reduces MDA in the kidney, it has a significant oxidant effect in terms of AOPP. In addition, the decrease of SOD in the kidney with EPO pretreatment is another finding supporting that EPO therapy may cause OS in the kidney. Moreover, EPO pretreatment increased the prolidase level in the kidney more than the increase caused by seizures. It is reported that increased tissue prolidase levels in diseases such as diabetes, chronic liver disease are an indicator of OS and the reduction of antioxidant defense could cause increase in prolidase level (37). Indeed, in our study, in the EPO-treated group the kidney SOD levels reduced, while prolidase level increased. All these findings strengthen the theory that EPO pretreatment can cause OS in the kidney. The Kidneys are the primary site of EPO production and contain more EPOr, which have higher affinity. Therefore, we think that exogeneously given EPO may arise from the affinity differences of the EPOr in hematopoietic organ, the kidney and nonhematopoietic organs, and the differences in the dynamics of the signal pathways initiated through these receptors. Meanwhile, our findings revealed that EPO treatment before seizure is ineffective to changes in SA levels in the heart and kidney caused of seizures. Namely, the SA level was high in heart tissue and low in kidney tissue as in the PTZ group. On the other hand, interestingly EPO treatment prevented the increase in AOPP caused by PTZ in the liver. This finding at the same time shows the protective effect of EPO in the liver.

\section{CONCLUSION}

Our results clearly showed that seizures cause OS in the liver and kidneys and increase SA in heart tissue. We suggest that increased SA in the heart is an important and original result that may be critical for seizure related cardiac arrythmias and/or sudden deaths. Our study clearly showed that EPO suppresses PTZ-induced seizures, as we have shown earlier. Furthermore, our results revealed that EPO pretreatment affected the changes in OS markers caused by seizures in tissues, but this effect was different according to the tissue, increased protein oxidaiton and prolidase, especially in the kidney. While investigating the anti-epileptic effect of EPO in seizures, its effect on tissues has not been studied before, and thus limits our discussion. Although there is no parameter showing the effect of EPO on glutamate receptors in peripheral tissues in our study, we suggest that EPO may show different effects on tissues due to the different glutamate receptors expressed in peripheral tissues. Indeed, glutamate receptors, which play a critical role in the initiation 
and spread of seizures, have been detected in peripheral tissues including the heart and kidney and it is reported that the glutamate receptors may mediate the functions of tissues (38). Our preliminary study clearly shows that while investigating the anti-epileptic effect of EPO, its effect on tissues must not be ignored. We think that further studies are needed to understand the mechanism.

Ethics Committee Approval: This study was approved from by the Bezmialem Vakif University, Animal Experiments Local Ethics Committee (Date: 22.04.2016, No:128).

Peer Review: Externally peer-reviewed.

Author Contributions: Conception/Design of Study- A.K., Z.K., K.A.D., G.Ü.; Data Acquisition- A.K., K.A.D., I.K.; Data Analysis/ Interpretation- Z.K., i.K., G.Ü.; Drafting Manuscript- G.Ü.; Critical Revision of Manuscript- A.K., Z.K., K.A.D., I.K., G.Ü.; Final Approval and Accountability- A.K., Z.K., K.A.D., I.K., G.Ü.

Conflict of Interest: Authors declared no conflict of interest.

Financial Disclosure: Authors declared no financial support.

Etik Komite Onayı: Bu çalışma için etik komite onayı Bezmialem Vakıf Üniversitesi, Hayvan Deneyleri Yerel Etik Kurulu'ndan alınmıştır (Tarih: 22.04.2016, No:128).

Hakem Değerlendirmesi: Dış bağımsız.

Yazar Katkıları: Çalışma Konsepti/Tasarım- A.K., Z.K., K.A.D., G.Ü.; Veri Toplama- A.K., K.A.D., I.K.; Veri Analizi/YorumlamaZ.K., i.K., G.Ü.; Yazı Taslağı- G.Ü.; İçeriğin Eleştirel InncelemesiA.K., Z.K., K.A.D., I.K., G.Ü.; Son Onay ve Sorumluluk- A.K., Z.K., K.A.D., I.K., G.Ü.

Çıkar Çatışması: Yazarlar çıkar çatışması beyan etmemişlerdir.

Finansal Destek: Yazarlar finansal destek beyan etmemişlerdir.

\section{REFERENCES}

1. Hamed SA. The effect of antiepileptic drugs on the kidney function and structure. Expert Rev Clin Pharmacol 2017;10(9):993-1006. [CrossRef]

2. Dillioglugil MO, Kir HM, Demir C, Ilbay G, Sahin D, Dillioglugil $O$, et al. Effect of pentylenetetrazole and sound stimulation induced single and repeated convulsive seizures on the MDA, GSH and NO levels, and SOD activities in rat liver and kidney tissues. Brain Res Bull 2010;83(6):356-9. [CrossRef]

3. Willmore LJ, Wilder BJ, Bruni J, Villarreal HJ. Effect of valproic acid on hepatic function. Neurology 1978;28(9 Pt 1):961-4. [CrossRef]

4. Arcasoy MO. Non-erythroid effects of erythropoietin. Haematologica 2010;95(11):1803-5. [CrossRef]

5. Chu K, Jung KH, Lee ST, Kim JH, Kang KM, Kim HK, et al. Erythropoietin reduces epileptogenic processes following status epilepticus. Epilepsia 2008;49(10):172332. [CrossRef]
6. Üzüm G, Sarper Diler A, Bahçekapılı N, Ziya Ziylan Y. Erythropoietin prevents the increase in blood-brain barrier permeability during pentylentetrazol induced seizures. Life Sci 2006;78(22):2571-6. [CrossRef]

7. Bahçekapılı N, Akgün-Dar K, Albeniz I, Kapucu A, Kandil A, Yağız $O$, et al. Erythropoietin pretreatment suppresses seizures and prevents the increase in inflammatory mediators during pentylenetetrazole-induced generalized seizures. Int J Neurosci 2014;124(10):762-70. [CrossRef]

8. Abdelrahman M, Sharples EJ, McDonald MC, Collin M, Patel NS, Yaqoob MM, et al. Erythropoietin attenuates the tissue injury associated with hemorrhagic shock and myocardial ischemia. Shock 2004;22(1):63-9. [CrossRef]

9. Patel NS, Sharples EJ, Cuzzocrea S, Chatterjee PK, Britti D, Yaqoob MM, et al. Pretreatment with EPO reduces the injury and dysfunction caused by ischemia/reperfusion in the mouse kidney in vivo. Kidney Int 2004;66:983-9. [CrossRef]

10. Akbas SH, Yegin A, Ozben T. Effect of pentylenetetrazolinduced epileptic seizure on the antioxidant enzyme activities, glutathione and lipid peroxidation levels in rat erythrocytes and liver tissues. Clin Biochem 2005;38(11):1009-14. [CrossRef]

11. Tigaran S, Molgaard $H, M c C$ lelland R, Dam M, Jaffe AS. Evidence of cardiac ischemia during seizures in drug refractory epilepsy patients. Neurology 2003;60(3):492-5. [CrossRef]

12. Surges R, Sander JW. Sudden unexpected death in epilepsy: mechanisms, prevalence, and prevention. Curr Opin Neurol 2012;25(2):201-7. [CrossRef]

13. Zimmer T, Haufe V, Blechschmidt S. Voltage-gated sodium channels in the mammalian heart. Glob Cardiol Sci Pract 2014;(4):449-63. [CrossRef]

14. Bennett E, Urcan MS, Tinkle SS, Koszowski AG, Levinson SR. Contribution of sialic acid to the voltage dependence of sodium channel gating. A possible electrostatic mechanism. J Gen Physiol 1997;109(3):327-43. [CrossRef]

15. Liu G, Nakayama K, Awata S, Tang S, Kitaoka N, Manabe $M$, et al. Prolidase isoenzymes in the rat: their organ distribution, developmental change and specific inhibitors. Pediatr Res 2007;62(1):54-9. [CrossRef]

16. Surazynski A, Miltyk W, Palka J, Phang JM. Prolidasedependent regulation of collagen biosynthesis. Amino Acids 2008;35(4):731-8. [CrossRef]

17. Duygu F, Koruk ST, Karsen H, Aksoy N, Taskin A, Hamidanoglu M. Prolidase and oxidative stress in chronic hepatitis C. J Clin Lab Anal 2012;26(4):232-7. [CrossRef]

18. Karacan N, Çalik M, Kazanasmaz H, Ethemoğlu Ö, Güzelçiçek $A$, Yaşin $S$, et al. The serum prolidase enzyme activity as a biomarker for evaluation of the subclinical vascular damage in children with epilepsy. Ann Indian Acad Neurol 2020;23(6):787-91.

19. Kapucu A, Üzüm G, Kaptan Z, Akgün-Dar K. Effects of erythropoietin pretreatment on single dose pentylentetrazole-induced seizures in rats. Biotech Histochem 2020;95(6):418-27. [CrossRef]

20. Lüttjohann A, Fabene PF, van Luijtelaar GA. Revised Racine's scale for PTZ-induced seizures in rats. Physiol Behav 2009;98(5):579-86. [CrossRef]

21. Lowry $\mathrm{OH}$, Rosebrough NJ, Farr AL, Randall J. Protein measurement with the folin phenol reagent. J Biol Chem 1951;193(1):265-75. [CrossRef] 
22. Hanasand M, Omdal R, Norheim KB, Gøransson LG, Brede C, Jonsson G. Improved detection of advanced oxidation protein products in plasma. Clin Chim Acta 2012;413(910):901-6. [CrossRef]

23. Buege JA, Aust SD. Microsomal lipid peroxidation. Methods Enzymol 1978;52:302-10. [CrossRef]

24. Tram TH, Brand Miller JC, McNeil Y, McVeagh P. Sialic acid content of infant saliva: comparison of breast fed with formula fed infants. Arch Dis Child 1997;77(4):315-8. [CrossRef]

25. Sun Y, Oberley LW, Li Y. A simple method for clinical assay of superoxide dismutase. Clin Chem 1988;34(3):497-500. [CrossRef]

26. Ozcan O, Gultepe M, Ipcioglu O, Bolat B, Kayadibi H. Optimization of the photometric enzyme activity assay for evaluating real activity of prolidase. Turk $\mathrm{J}$ Biochem 2007;32(1):12-6.

27. Uma Devi P, Pillai KK, Vohora D. Modulation of pentylenetetrazole-induced seizures and oxidative stress parameters by sodium valproate in the absence and presence of $\mathrm{N}$-acetylcysteine. Fundam Clin Pharmacol 2006;20(3):247-53. [CrossRef]

28. Maes $M$, Supasitthumrong $T$, Limotai $C$, Michelin $A P$, Matsumoto AK, de Oliveira Semão L, et al. Increased oxidative stress toxicity and lowered antioxidant defenses in temporal lobe epilepsy and mesial temporal sclerosis: associations with psychiatric comorbidities. Mol Neurobiol 2020;57(8):3334-48. [CrossRef]

29. Ercegovac M, Jovic N, Simic T, Beslac-Bumbasirevic L, Sokic D, Djukic $T$, et al. Byproducts of protein, lipid and DNA oxidative damage and antioxidant enzyme activities in seizure. Seizure 2010;19(4):205-10. [CrossRef]
30. Gill SS, Pulido OM. Glutamate receptors in peripheral tissues: current knowledge, future research, and implications for toxicology. Toxicol Pathol 2001;29(2):208-23. [CrossRef]

31. Sharma A. Monosodium glutamate-induced oxidative kidney damage and possible mechanisms: a mini-review. J Biomed Sci 2015;22:93. [CrossRef]

32. Lindberg G, Eklund GA, Gullberg B, Råstam L. Serum sialic acid concentration and cardiovascular mortality. BMJ 1991;302(6769):143-6. [CrossRef]

33. Crook M, Haq M, Haq S, Tutt P. Plasma sialic acid and acute-phase proteins in patients with myocardial infarction. Angiology 1994;45(8):709-15. [CrossRef]

34. Babal P, Slugen I, Danis D, Zaviacic M, Gardner WA Jr. Sialic acid expression in normal and diseased human kidney. Acta Histochem 1996;98(1):71-7. [CrossRef]

35. Purves D, Augustine GJ, Fitzpatrick D, Katz LC, LaMantia A-S, McNamara JO, Williams SM, editors. Neuroscience 2nd edition. Glutamate Receptors in Chapter 7. Oxford Unıversity Press, Oxford, Sinauer Associates; 2001.

36. Pasaoglu H, Ofluoglu Demir FE, Y,Imaz Demirtas C, Hussein A, Pasaoglu OT. The effect of caffeine on oxidative stress in liver and heart tissues of rats. Turkish $\mathrm{J}$ of Med Sci 2011;41:665-71.

37. Myara I, Myara A, Mangeot M, Fabre M, Charpentier C, Lemonnier A. Plasma prolidase activity: a possible index of collagen catabolism in chronic liver disease. Clin Chem 1984;30(2):211-5. [CrossRef]

38. Gu L, Xu H, Wang F, Xu G, Sinha D, Wang J, et al. Erythropoietin exerts a neuroprotective function against glutamate neurotoxicity in experimental diabetic retina. Invest Ophthalmol Vis Sci 20114;55(12):8208-22. [CrossRef] 